\title{
THE ANALYSIS OF SERVICE SATISFACTION LEVEL IN THE IMPLEMENTATION OF TEACHER PROFESSIONAL EDUCATION PROGRAM IN 2020
}

\author{
Fatkur Rohman Kafrawi ${ }^{*}$, Syamsul Sodiq ${ }^{2}$, Julianto ${ }^{3}$ \\ ${ }^{1}$ Jurusan IKOR FIO, Universitas Negeri Surabaya, Lidah Wetan \\ ${ }^{2}$ Jurusan Sastra Indonesia FBS, Universitas Negeri Surabaya, Lidah Wetan \\ ${ }^{3}$ Jurusan PGSD FIP, Universitas Negeri Surabaya, Lidah Wetan \\ Surabaya, 64732, Indonesia \\ faturrohman@unesa.ac.id*
}

\begin{abstract}
The purpose of this research is to identify and to obtain various information related to the level of service satisfaction in the implementation of Teacher Professional Program in 2020. The type of research used is descriptive research. The population in this study were all Teacher Professional Education Program participants in stages 1-4, totaling 1632 students consisting of 15 study programs at the State University of Surabaya. The sample used in this study was 971 students of the Teacher Professional Education Program of 2020 academic year. The data collection method used was a questionnaire. The questionnaire developed by the researchers has 6 indicators including: (1) LMS (Learning Management System), (2) Helpdesk Teacher Professional Education Program IT team, (3) Teacher Professional Education Program Instructors (Lecturers), (4) In-service teachers, (5) Participants, and (6) Material. The data obtained were analyzed descriptively, qualitatively and quantitatively. Based on the results and discussion, it can be concluded that the level of service satisfaction in the implementation of Teacher Professional Education Program in 2020 is good. In addition, it is also supported by the results of the six indicators showing the satisfaction of students who take Teacher Professional Education Program in position 2020 which was held online. Although in general it runs smoothly in the implementation of Teacher Professional Education Program in Position in 2020, however there were still some shortcomings or obstacles that arise in the implementation, especially interactions in the LMS both with instructors, tutors, helpdesk and the learning management system itself.
\end{abstract}

Keywords: Teacher Professional Education Program, Certification, LMS, Descriptive Study.

Abstrak: Tujuan penelitian ini adalah untuk mengidentifikasi dan mendapatkan berbagai informasi terkait tingkat kepuasan pelayanan dalam pelaksanaan PPG Dalam Jabatan tahun 2020. Jenis penelitian yang digunakan adalah penelitian deskriptif. Adapun populasi dalam penelitian ini yaitu seluruh peserta PPG Dalam Jabatan tahap 1-4 yang berjumlah 1632 mahasiswa terdiri 15 Prodi yang ada di Universitas Negeri Surabaya. Sampel yang digunakan dalam penelitian ini sebanyak 971 mahasiswa yang mengikuti PPG Daljab tahun 2020. Metode pengumpulan data yang digunakan yakni angket. Angket yang dikembangkan oleh peneliti memiliki 6 indikator diantaranya: (1) LMS, (2) Helpdesk tim IT PPG, (3) Instruktur PPG (Dosen), (4) Guru Pamong, (5) Peserta, dan (6) Materi. Data yang diperoleh akan dianalisis secara deskriptif kualitatif dan kuantitatif. Berdasarkan hasil dan pembahasan dapat disimpulkan tingkat kepuasan pelayanan dalam pelaksanaan PPG Dalam Jabatan tahun 2020 baik. Selain itu juga, didukung hasil dari keenam indikator menunjukkan kepuasan dari mahasiswa yang mengikuti PPG Dalam Jabatan tahun 2020 yang dilaksanakan secara daring. Walaupun secara garis besar berjalan dengan lancar dalam pelaksanaan PPG Dalam Jabatan tahun 2020, tentunya masih ada beberapa kekurangan atau hambatan yang muncul dalam pelaksanaan terutama interaksi dalam LMS baik dengan instruktur, guru pamong, helpdesk dan system lms itu sendiri.

Kata Kunci: PPG Dalam Jabatan, Sertifikasi, LMS, Studi Deskriptif. 


\section{INTRODUCTION}

The mandate of Law Number 14 of 2005 concerning Teachers and Lecturers Article 8 states that teachers are required to have academic qualifications, competencies, teacher certificates, are physically and mentally healthy, and have the ability to realize the goals of national education. In Law Number 12 of 2012 concerning Higher Education Article 17 paragraph (1) states that professional education is higher education after an undergraduate program that prepares students for jobs that require special skills requirements. The Teacher Professional Education Study Program (PPG) is organized by the Education Personnel Education Institute (LPTK) with reference to Teacher Education Standards (DikGu Standards) and National Higher Education Standards (SNDikti). With the publication of these guidelines, it is hoped that the LPTK will always improve the quality of the implementation of the Teacher Professional Education Program so that it can produce graduate teacher candidates who are able to prepare students to face increasingly complex challenges in the 21 st century and make a positive contribution to realizing the goals of sustainable development.

Based on the memorandum of understanding between the Director of Professional Education and Teacher Development and Education Personnel of the Ministry of Education and Culture, and the Rector of the State University of Surabaya, Number: 2744 / B2 / KS / 2020, Number 113 / UN.38 / KS / 2020, the first party and the second party agree collaborating in the implementation of self-management activities in accordance with the DIPA (Budget Implementation List) of the work unit of the Directorate of Professional Education and Teacher and Education Personnel Development, 2020 fiscal year, State University of Surabaya as the organizer of the teacher professional education program in office or self-managed implementer.

The Covid-19 pandemic is a health crisis that occurred in December 2019 which started in the Wuhan area of China. On March 11, 2020, the World Health Organization (WHO) set Corona Virus Disease 2019 to be an International Pandemic. This is evidenced by the issuance of Presidential Decree number 11 of 2020 concerning the Determination of the 2019 Corona Virus Disease Public Health Emergency (COVID-19). In this Presidential Decree, the President designated Corona Virus Disease 2019 (COVID-19) as a type of disease that causes a Public Health Emergency. Worse yet, it happened at a fast tempo and on a wide scale. This resulted in the implementation of professional education program which was carried out at on line.

The LP3M (Lembaga Pengembangan Pembelajaran dan Penjamian Mutu) of Teacher Professional Education Program which so far had been carried out face-to-face / offline. The implementation of professional education program cannot be carried out, due to the Covid-19 pandemic, then it carried out online using the Learning Management System (LMS) media, teleconference, WAG (whatsapp group), zoom, and google meeting. The implementation of online Teacher Professional Education Program will certainly have an effect on the acquisition of information, which is explained both by the center of the Ministry of Education and Culture, in this case the GTK (guru dan tenaga kependidikan) and the LP3M managers. The implementation of Teacher Professional Education Program in 2020, both lecturers and tutors and students involved in this activity do it fully online using LMS facilities that have been developed by the Ministry of Education and Culture. The State University of Surabaya has won the trust to implement Teacher Professional Education Program for 4 stages with 1,665 students in total taken from the state budget costs, consisting of 15 fields of study from various regions of Indonesia. The human resources involved as the committee were 127 people, 218 lecturers and 159 pamong teachers from August to December 2020. The implementation activities of Teacher Professional Education Program, which time intersect one stage with another, are one of the influencing factors in producing graduates who are competent in fields. Therefore, it is necessary to conduct a study to obtain information that can be used to improve graduates and services in the implementation of Teacher Professional Education Program activities in the following year.

The government's commitment to educating the nation's life is the mandate of the Preamble of the 1945 Constitution (UUD 1945) as written in the fourth paragraph which states that "..... Then from that to form an Indonesian State Government that protects the entire Indonesian nation 
and all of it spills over. Indonesian blood and to promote general welfare, to educate the nation's life,.....". In addition, in Article 31 paragraph (3) of the amended 1945 Constitution, it is stated that the Government shall endeavor and implement a national education system that enhances faith and piety and noble character in the framework of the intellectual life of the nation, which is regulated by law.

2005 was a milestone in the appreciation and protection of the teaching profession. This year, the government passed Law No. 14 of 2005 on Teachers and Lecturers which also known as UUGD (Undang-Undang Guru dan Dosen). This law states that a teacher is a professional position. UUGD Article 1 (1) states that teachers are professional educators with the main task of educating, teaching, guiding, directing, training, assessing, and evaluating students in early childhood education through formal education, basic education and secondary education.

Furthermore, Article 8 UUGD states that teachers are required to have academic qualifications, competencies, teacher certificates, be physically and mentally healthy, and be able to realize the goals of national education. Article 11 paragraph (1) Educator certificates are given to teachers who have met the requirements, paragraph (2) Educator certification is held by tertiary institutions that have an accredited education personnel procurement program stipulated by the Government, and paragraph (3) Educator certification is carried out objectively. transparent, and accountable.

To realize the mandate of the law in preparing professional teachers, the government has prepared a Teacher Professional Education Program (PPG) in the form of a Teacher Professional Education Study Program. The Teacher Professional Education Program in Indonesia in accordance with the mandate of the law, both UUGD and Law Number 12 of 2012 concerning Higher Education, adopts a consecutive or layered model. Article 17 (1) of the Higher Education Law states that professional education is higher education after an undergraduate program that prepares students for jobs that require special skills requirements.

The Teacher Professional Education Study Program is an educational program that is held to prepare non-educational undergraduate who have the talent and interest in becoming a teacher in order to fully master teacher competencies in accordance with Teacher Education Standards so that they can obtain a professional educator certificate in early childhood education, primary education, and secondary education.

The Teacher Professional Education Study Program is expected to be able to answer various educational problems, such as: (1) shortage of teachers (shortage), especially in outermost, frontier, and underdeveloped areas, (2) unbalanced distribution, (3) below qualifications standards (under qualification), (4) teachers who are less competent (low competence), and (5) mismatch between educational qualifications and the field being managed (missmatched). In addition, teachers in this digital 4.0 era must have the ability to carry out innovative and fun learning by integrating critical thinking and problem solving, communication and collaborative skills, creativity and innovative skills, information and communication technology literacy, contextual learning skills, and information and media literacy. through the TPACK (Technological, Pedagogical, Content Knowledge) approach.

The Teacher Professional Education Study Program which is designed systematically and applies quality principles ranging from selection, learning process, and assessment, to competency testing, is expected to produce future professional teachers who can produce graduates who are superior, competitive, have character, and have a strong feeling toward the country, is expected to be able to answer the educational problems facing the Indonesian nation today.

Online Teacher Professional Education activities are grouped into three subject groups, namely (1) deepening of pedagogic material and fields of study, (2) developing learning tools, and (3) practicing field experiences. Subjects for deepening pedagogic materials and fields of study are conducted online with a learning load of 5 credits. This course facilitates students to strengthen their understanding of professionalism, pedagogy, and subject matter by utilizing information and communication technology in online and independent learning through LMS and other sources. The profession of teachers needs to be supported by a deep understanding of 
learning theory, educational psychology, socio-culture, social construction, and diversity. The deepening of pedagogical material includes planning, implementing, and evaluating educational learning. The deepening of subject matter includes essential materials including advance materials in the field of study that can explain the "what" (content), "why" (philosophy), and "how" (application) aspects in everyday life. The deepening of the subject matter is also directed at developing higher order thinking skills (HOTS). This online learning begins one month before the learning device development workshop, is conducted under the guidance of an online lecturer and continues as long as the Teacher Professional Education Program takes place independently.

The course of developing learning devices has a learning load of 3 credits. In its implementation, this course is divided into 2 activities, namely, the development of learning tools ( 2 credits) and review of learning tools $(1$ credit). This course facilitates students to develop learning tools by utilizing the results of deepening professional, pedagogical, and field of study materials in the form of workshops. The development of learning tools includes curriculum analysis, designing educational activities and assessments of learning with the Technological Pedagogical and Content Knowledge (TPACK) approach based on the industrial revolution 4.0 platform. Educational activity design and assessment by integrating critical thinking, creative thinking, reflective thinking and decision making abilities into learning activities through inquiry based activities. The product of this workshop is a learning tool that includes a Learning Implementation Plan (RPP), teaching materials, media, Student Worksheets, and learning evaluation tools. The learning tools that have been developed are implemented in the form of a new peerteaching model and a reflection ends after learning.

The Field Experience Practice course has a learning load of 4 credits. In its implementation, this course is divided into 2 activities, namely, field experience practice ( 3 credits), and field experience practice review and reflection (1 credit). This course facilitates students to develop professional skills as teachers who have the main task of educating, teaching, guiding, directing, training, assessing, and evaluating students in the form of teaching practices. This course also facilitates students to carry out non-teaching tasks in the form of activities to do class administration, school administration, foster co-curricular, extracurricular activities, and participate in other school activities. For the vocational field, non-teaching activities include visits to the business world and the industrial world. This course is also directed at forming a charming teacher, one based on an attitude of love for the country, with dignity, assertiveness, discipline, full of soul calling, samapta, accompanied by a spirit of wholeheartedness and generosity. In addition to developing teacher professionalism, field experience practice is also to develop leadership skills. All activities ended with reflections which were carried out regularly with the guidance teachers and field supervisors. Based on the teacher education standard, the learning load for the Teacher Professional Education program is 36 - 40 credits. For Teacher Professional Education in Position, the learning load that must be taken is 12 credits, while the 24 credits of learning load are fulfilled through the recognition of past learning.

\section{METHODS}

This research is a descriptive qualitative research which provides a deep overview of the object under study based on the collected data (Sugiyono, 2012). Therefore, the researcher used a descriptive analysis in the form survey method because it was deemed suitable for knowing the phenomenon that was currently taking place. The phenomenon that will be described in this study is related to the level of service satisfaction in the implementation of Teacher Professional Education Program (PPG) in 2020 academic year, which carried out by LP3M (Lembaga Pengembangan Pembelajaran dan Penjamian Mutu) of Surabaya State University's Teacher Professional Education Program during the Covid-19 pandemic.

The subjects in this study were 1632 Teacher Professional Education Program students that consist of 15 study programs at the State University of Surabaya. The data collection technique was a questionnaire. The questionnaire developed by the researchers has 6 indicators that were used to obtain complete information regarding the implementation activities of Teacher 
Professional Education Program in 2020. The indicators in the questionnaire included: (1) LMS, (2) Helpdesk PPG IT team, (3) PPG Instructors (Lecturers), (4) Pamong Teachers, (5) Participants, and (6) Materials. The data obtained were analyzed in a descriptive qualitative manner which described the level of service satisfaction in the implementation of PPG in Position in 2020 during the Covid-19 pandemic.

\section{RESULTS AND DISCUSSION}

\section{Research results}

In this study, the research subjects were Teacher Professional Education Program students in 2020 who were implemented using online Learning Management System (LMS). This Learning Management System (LMS) was developed by the Ministry of Education and Culture's IT team. For more details related to the distribution of study programs, gender, and participants at each stage of the Teacher Professional Education Program, it can be seen in the following Graph1.
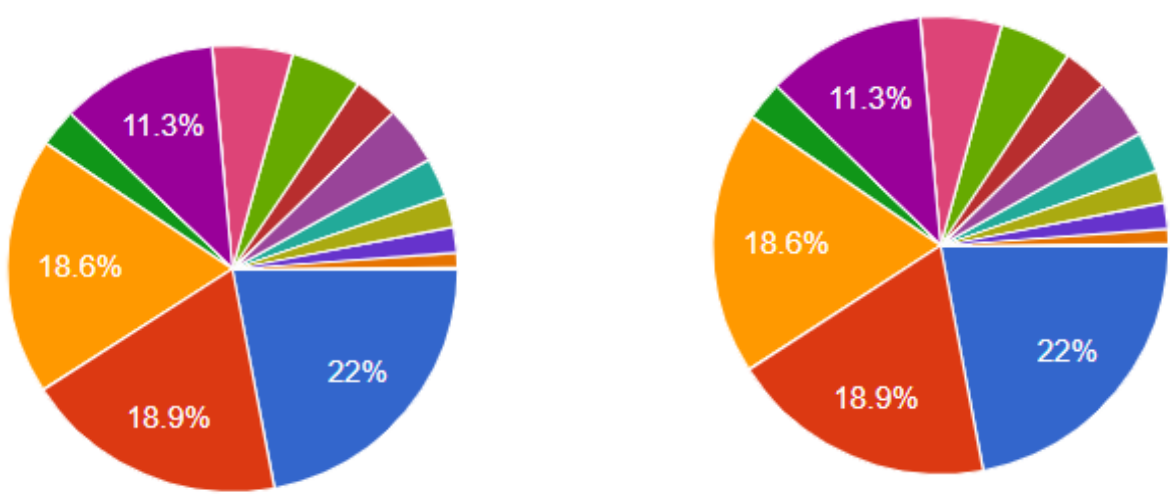

Graph 1. Distribution of Teacher Professional Education Program study programs in Surabaya State University

According to Graph 1, it can be seen that 3 study programs have a large number of Teacher Professional Education Program students, namely; (1) Science Study Program as much as $18.6 \%$, (2) Kindergarten Class Teacher Study Program (22\%), and (3) Elementary Class Teacher Study Program as much as $18.9 \%$. For the distribution of Teacher Professional Education Program student respondents in 2020 based on gender according to the data collected by researchers using a questionnaire distributed via google form, it can be presented in Figure 2 below.

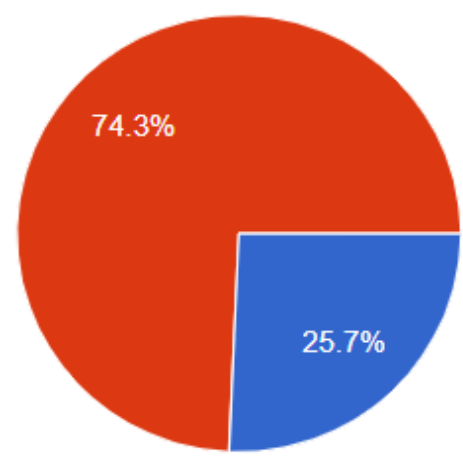

Graph 2. Distribution of Teacher Professional Education Program students according to gender 
Based on the graph above, we can see that the number of our Teacher Professional Education Program students according to gender is 74,\% female and $25.7 \%$ male. For the distribution of Teacher Professional Education Program students based on the implementation stages in Teacher Professional Education Program LP3M Unesa, namely stages 1-4, more specifically can be seen in Graph 3 as follows.

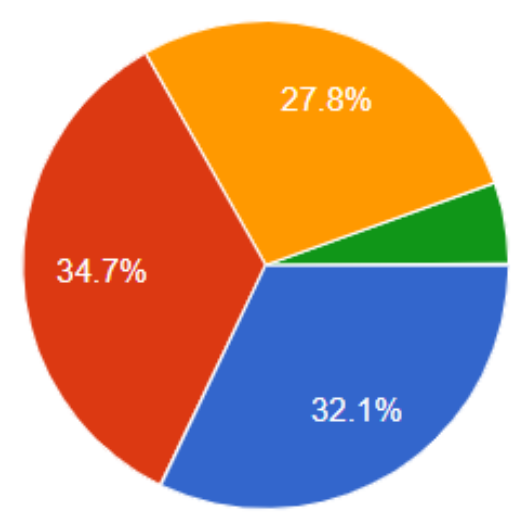

Graph 3. Distribution of Teacher Professional Education Program students according to the implementation stage

Referring to the graphic above, we can find out the number of Teacher Professional Education Program students who participated based on the implementation stages, namely; (1) stage 1 was $32.1 \%$ around 340 students, (2) stage 2 was $34.7 \%$ around 367 students, (3) stage 3 was $27.8 \%$ about 294 students, and (4) stage 4 was $4,3 \%$ about 54 students. In accordance with the research objectives stated in CHAPTER I, namely to identify and obtain various information related to the level of service satisfaction in the implementation of Teacher Professional Education Program in Position in 2020. In this study, instruments used to collect research data have been produced and have been validated by experts. This research instrument has also been digitized using google form and the distributed questionnaire to the Teacher Professional Education Program students from November to December 2020. The results of the distributed questionnaire can be seen in Graph 4 - 9 below.

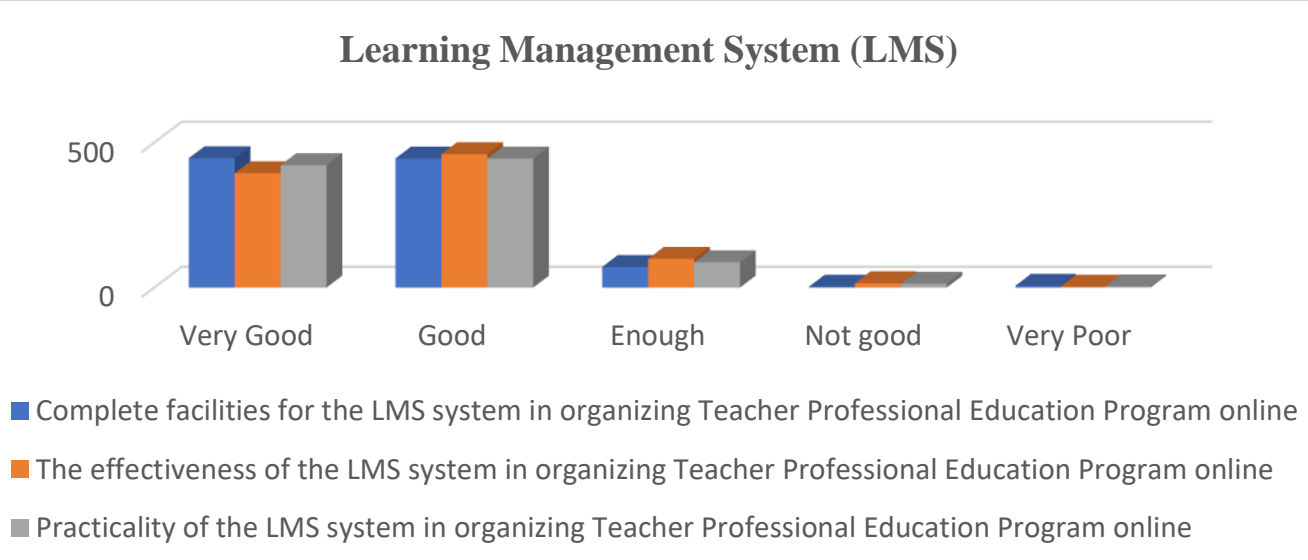

Graph 4. Responses given by Teacher Professional Education Program students for the first indicator 


\section{Helpdesk Teacher Professional Education Program IT Team}

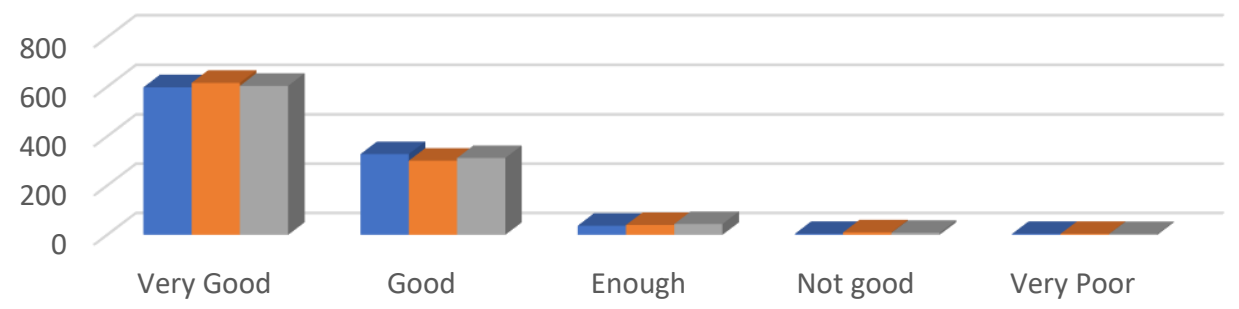

— IT Teacher Professional Education Program Helpdesk has adequate IT mastery

- Helpdesk has a communicative attitude to each Teacher Professional Education Program participant

IT Teacher Professional Education Program Helpdesk has a responsive attitude

Graph 5. Responses given by Teacher Professional Education Program students for the second Indicator

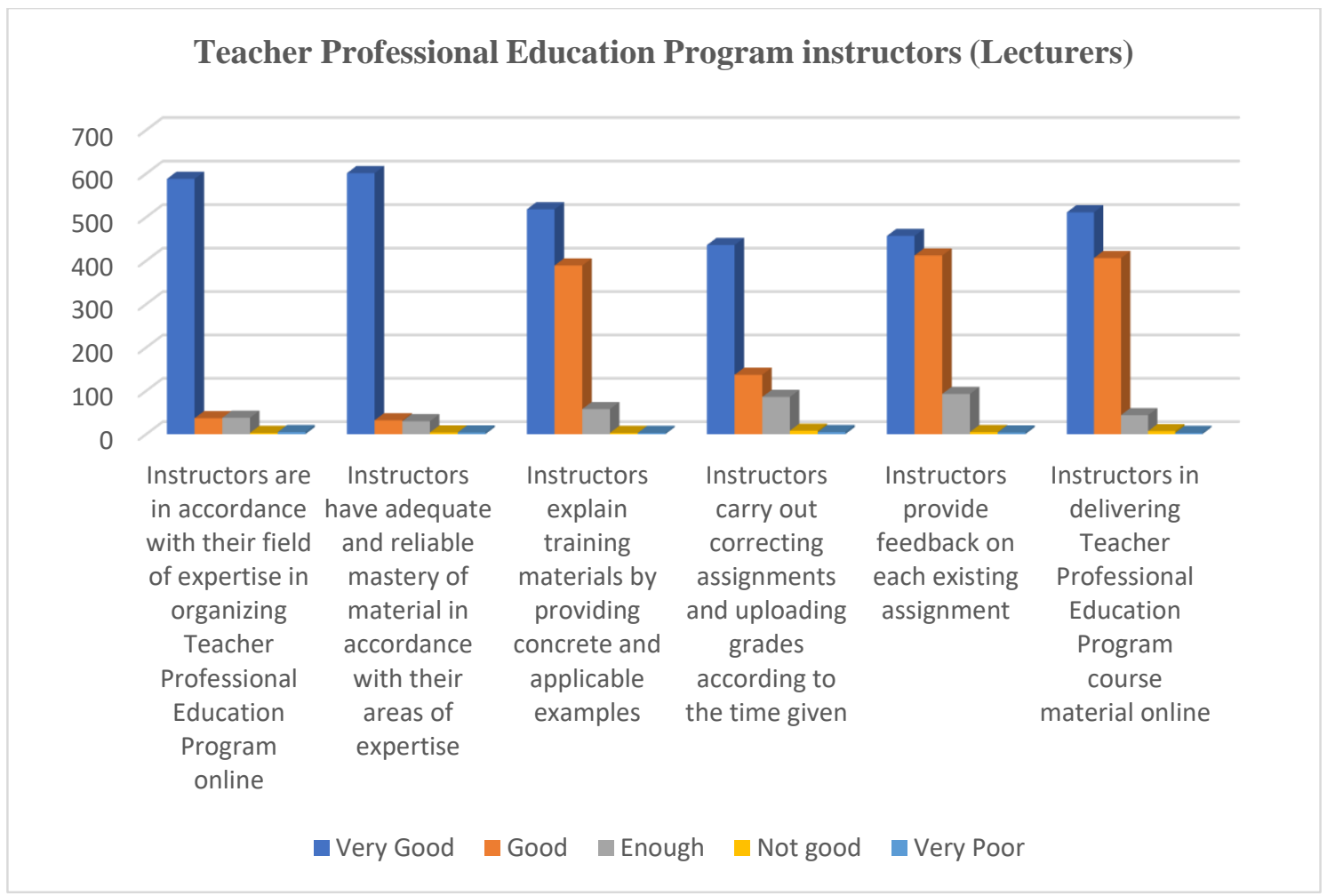

Graph 6. Responses given by Teacher Professional Education Program students for the third indicator 


\section{In-service teachers}

0

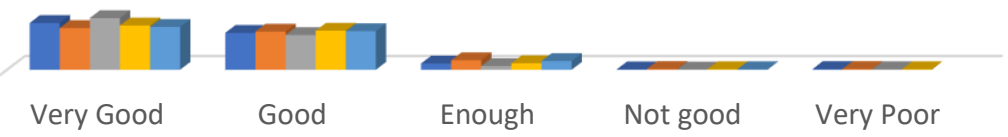

- Pamong teachers who are involved in mentoring have adequate mastery of the material

- Pamong teachers make assignments corrections and upload scores according to the time given

- Pamong teachers who are involved in mentoring according to their areas of expertise

nutoring teachers in delivering material or suggestions that are concrete and applicable, and

- the tutor gives feedback on each existing assignment

Graph 7. Responses given by Teacher Professional Education Program students for the fourth indicator

\section{Participants}

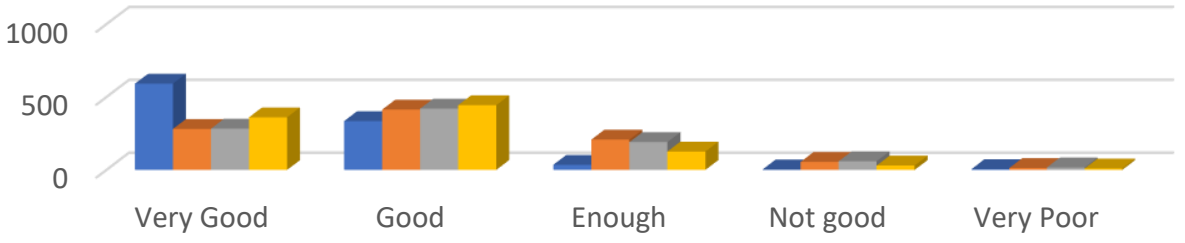

- Participants upload the assignment according to the time allotted for each module

The time given to read the material for each module in the LMS

The time given to complete the task for each module in the LMS

The time given to complete each formative test in each module

Graph 8. Responses given by Teacher Professional Education Program students for the fifth indicator

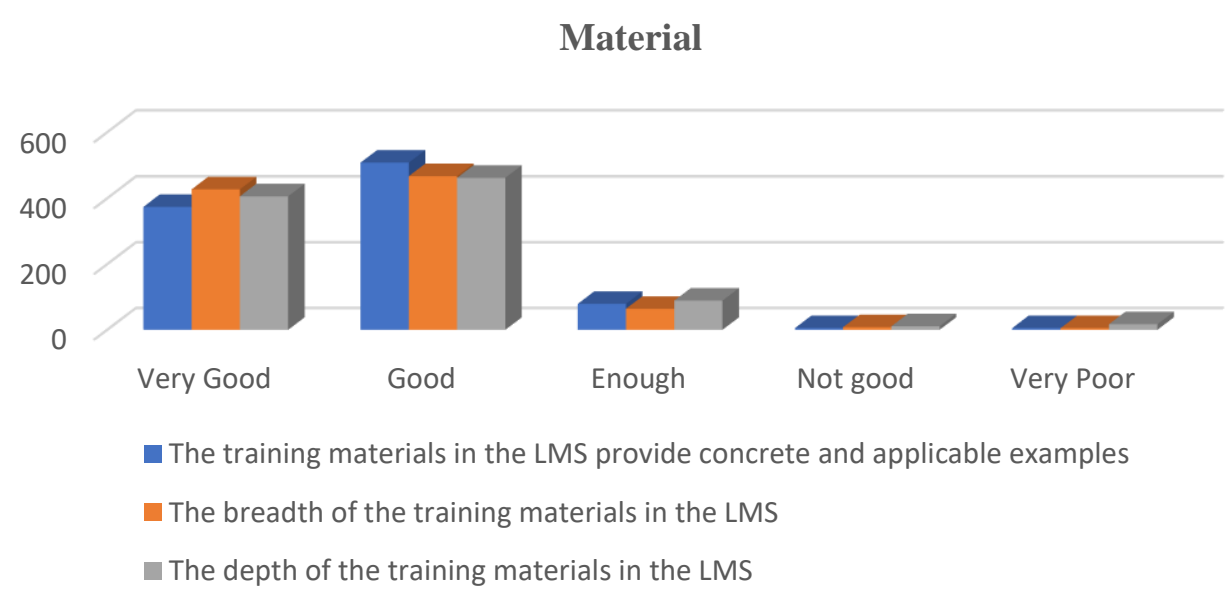

Graph 9. Responses given by Teacher Professional Education Program students for the sixth indicator 
Based on the results obtained in this study, it can be seen that the level of service satisfaction in the implementation of Teacher Professional Education Program in Position in 2020 during the Covid-19 pandemic is very good. This is shown by the responses given by Teacher Professional Education Program students to the six indicators used when filtering responses using a questionnaire and digitizing them in a google form which is addressed at the (Url. https://forms.gle./CQN1hD2zpRgUsDtZA). In more detail, each indicator used in capturing responses will be discussed regarding the level of service satisfaction in the implementation of Teacher Professional Education Program in Position in 2020.

The I LMS indicator, the first indicator has 3 sub indicators, namely; (1) Complete facilities for the LMS system in organizing Teacher Professional Education Program online, (2) The effectiveness of the LMS system in organizing Teacher Professional Education Program online, and (3) Practicality of the LMS system in organizing Teacher Professional Education Program online. The three sub indicators get responses from Teacher Professional Education Program students in position with good - very good criteria, with an average of 420 - 450.This shows that the LMS developed by the Ministry of Education and Culture's GTK used in Teacher Professional Education Program in Position in 2020 is in accordance with the needs and challenges to create professional teachers with the TPACK approach in its implementation. For the sub-indicators of practicality in the LMS, there were 15 students who gave unfavorable responses, this shows that not all students who take Teacher Professional Education Program in position can use or operate the LMS properly. Therefore, in the future it is necessary to have a pocket book containing an explanation of the use of the LMS so that Teacher Professional Education Program students in the position will be more familiar or easier to understand the menus or features in the LMS.

Indicator 2 Helpdesk Teacher Professional Education Program IT Team, the second indicator has sub-indicator 3 namely; (1) IT Teacher Professional Education Program Helpdesk has adequate IT mastery, (2) Helpdesk has a communicative attitude to each Teacher Professional Education Program participant, and (3) IT Teacher Professional Education Program Helpdesk has a responsive attitude. The three sub-indicators used in this second indicator also received an extraordinary response from Teacher Professional Education Program students in occupation who had participated in Teacher Professional Education Program in Position in 2020. This second indicator received a response from Teacher Professional Education Program students in positions in general with good - very good criteria, with on average 313 - 606. This shows that the helpdesk in charge of implementing Teacher Professional Education Program in Position in 2020 has adequate IT mastery, communicative attitudes, and responsiveness. For the second sub indicator, there were several Teacher Professional Education Program students in positions who gave responses as many as 10 people with unfavorable criteria. Therefore, for the helpdesk team in the future, in implementing Teacher Professional Education Program in Position, it is necessary to improve a communicative attitude towards any input or complaint submitted by students so that they are quickly resolved. In addition, there will also be an evaluation of each stage of the implementation of Teacher Professional Education Program in future positions so that the level of service satisfaction is getting better.

Indicator 3 Teacher Professional Education Program instructors (Lecturers), for this indicator has 6 sub indicators, including; (1) Instructors are in accordance with their field of expertise in organizing Teacher Professional Education Program online, (2) Instructors have adequate and reliable mastery of material in accordance with their areas of expertise, (3) Instructors explain training materials by providing concrete and applicable examples, (4) Instructors carry out correcting assignments and uploading grades according to the time given, (5) Instructors provide feedback on each existing assignment, and (6) Instructors in delivering Teacher Professional Education Program course material online. For the six sub indicators, in general, received a very good response from Teacher Professional Education Program students in the position in 2020. The fourth sub-indicator, there were 8 students who gave poor responses as many as 8 people related to making assignments corrections and uploading grades according to the time given in the LMS. This is due to the implementation of Teacher Professional 
Education Program in Position in 2020 when each stage intersects and lecturers also carry out learning assignments in class according to the schedule received from the study program, so that lecturers in providing assessments and corrections of Teacher Professional Education Program student assignments in the Position are disturbed. For future implementation regarding this fourth sub-indicator problem, it is necessary to have an agreement between Teacher Professional Education Program managers, instructors, and the Teacher Professional Education Program IT team regarding the schedule for filling out assessments and corrections. In addition, there will be more monitoring of each training course in the LMS, if it has not been assessed, the instructor will be contacted by the Teacher Professional Education Program IT team to immediately make corrections and assessments. Through these alternatives, it is hoped that there will be no more delays in making corrections and assessments on Teacher Professional Education Program student assignments in the next year's position.

Indicator 4 In-service teachers, or this indicator has 5 sub-indicators, including; (1) Pamong teachers who are involved in mentoring have adequate mastery of the material, (2) Pamong teachers make assignments corrections and upload scores according to the time given, (3) Pamong teachers who are involved in mentoring according to their areas of expertise, (4) Tutoring teachers in delivering material or suggestions that are concrete and applicable, and (5) the tutor gives feedback on each existing assignment. For all the sub-indicators in indicator 4, getting a response from Teacher Professional Education Program students in position in 2020 with good criteria - very good. This shows that the civil service teachers involved in implementing Teacher Professional Education Program in Position in 2020 are in accordance with the expected competencies and guidelines for the recruitment of civil service teachers who are intended to assist Teacher Professional Education Program. Even though each sub-indicator received a very good response from Teacher Professional Education Program students, there were still 8 people who gave an unfavorable response. The sub-indicator in question is that the civil service teacher corrects the assignment and uploads the value according to the time given, because there are some civil service teachers who are late in making corrections and assessments on Teacher Professional Education Program student assignments in positions at LMS, so that students feel uncomfortable and afraid of graduating. Therefore, in the future there needs to be an agreement between Teacher Professional Education Program administrators, tutors, and the Teacher Professional Education Program IT team so that these problems will not be repeated in the next Teacher Professional Education Program implementation. In addition, in the future there will be more intensive coordination between the manager, the helpdesk team, and related IT, so it will soon be discovered that the civil service teachers who have not made corrections and assessments on the LMS and immediately contact the person concerned to make corrections and assessments at the LMS. This alternative is expected to provide excellent service for the implementation of Teacher Professional Education Program in Position in the following year.

Indicator 5 participants, for this indicator has sub indicators totaling 4 aspects. These sub indicators include; (1) Participants upload the assignment according to the time allotted for each module, (2) The time given to read the material for each module in the LMS, (3) The time given to complete the task for each module in the LMS, and the time given to complete each formative test in each module. In general, this fifth indicator received a very good response from Teacher Professional Education Program students in position in 2020. Only a small proportion of participants in uploading assignments experienced difficulties. This is because a small number of participants for Teacher Professional Education Program in Position in 2020 are in areas that are difficult to signal so that if they upload their assignments, they have to go to cities or other areas where there is a signal, for example; participants from ponorogo in the mountains, participants from North Sulawesi, and others. The timing of implementing the Teacher Professional Education Program in Position in 2020, also overlaps with each other so that for LMS sometimes it is slow or troubled. This is because the LMS was developed by the center of the Ministry of Education and Culture's GTK in conjunction with the implementation of Teacher Professional Education Program in Position in 2020. Therefore, it is necessary to 
maintain the LMS system by GTK at night so that the time to read the module and work on formative tests on the module is also disturbed. Therefore, in the future the LMS must be clear and suitable for use and there is a guidebook that will make it easier for Teacher Professional Education Program students to understand the features in the LMS and the implementation time does not overlap so as to give students, tutors, and instructors time to do their activities in the future. LMS is more comfortable and quality. An alternative that can be done by the manager is by providing explanations or information on each activity in the LMS so that Teacher Professional Education Program students can share their time well and share time to do formative tests or summative tests that are in the LMS. It is hoped that this can increase the graduation rate of Teacher Professional Education Program students and increase the satisfaction of students who are participating in the implementation of Teacher Professional Education Program in the Position in the following year.

Indicator 6 is material, for this indicator it has 3 sub-indicators, namely; (1) The training materials in the LMS provide concrete and applicable examples, (2) the breadth of the training materials in the LMS, and (3) the depth of the training materials in the LMS. For this sixth indicator, all sub-indicators received responses from Teacher Professional Education Program students in position in 2020 with good - very good criteria. The third sub-indicator received some unfavorable responses from Teacher Professional Education Program students in the position related to the depth of the material. This is because there are some materials in the LMS that are not in sync with the fields of study that are currently taking part in the 2020 Teacher Professional Education Program in Position, for example: Mechanical engineering study program and Elementary Class Teacher Study Program. For the depth of the two study programs, the level is above or not in sync with the material. Therefore, in the future it is necessary to check the material in the LMS according to the Study Program that will carry out Teacher Professional Education Program and there will be no repeated errors. The alternatives that will be carried out in preparing the materials in the LMS are; (1) conduct an assessment of the UKMPPG grid, (2) develop a material module according to the results of the analysis, (3) validate with peers, (4) validate the experts / experts according to the developed module, (5) make revisions and finishing, and (6) uploading material modules to the LMS according to the Study Program. This alternative is used as an improvement in service improvement in the implementation of Teacher Professional Education Program in the following year and must be better than the previous year.

Based on the analysis and discussion carried out by researchers according to the data obtained, it can be said that the level of service satisfaction in implementing Teacher Professional Education Program in Position in 2020 is very good. This can be shown by the results of a questionnaire distributed through the goole form which contains 6 indicators for Teacher Professional Education Program students in position.

\section{CONCLUSIONS}

Based on the results and discussion, it can be concluded that the level of service satisfaction in the implementation of Teacher Professional Education Program in Position 2020 is good. This is shown by the responses given by Teacher Professional Education Program students in their position through a questionnaire distributed using google form. In addition, it is also supported by the results of the six indicators showing the satisfaction of students who take Teacher Professional Education Program in Position 2020 which is held online. Although in general it went well in the implementation of Teacher Professional Education Program in Position in 2020, of course there are still some shortcomings or obstacles that arise in the implementation, especially interactions in the LMS, both with instructors, tutors, helpdesk and the LM system itself.

In accordance with the results and discussion in this study, it is necessary to suggest some activities that can be used as improvements in the implementation of Teacher Professional 
Education Program in future positions. These suggestions include: It is necessary to develop a video tutorial related to the use of LMS, especially the preparation, debriefing, implementation, and preparation of Teacher Professional Education Program activity reports in position. It is necessary to have an activity journal that will be made by the participants as a form of progress every week carried out by the participants during the future Teacher Professional Education Program implementation activities. The depth and breadth of the material needs to be reviewed so that the material is in accordance with the field of study and there is no material misconception. Time in doing exercises in modules or formative tests needs to be reviewed by paying attention to the many questions that were tested or done by Teacher Professional Education Program students in their positions. There needs to be an agreement between the instructor and the tutor in providing assessments and feedback on the assignments that have been collected by Teacher Professional Education Program students in their position according to the specified time. The LMS system needs to be reviewed regarding the practicality of use during the implementation of Teacher Professional Education Program in the Position, so that the Teacher Professional Education Program learning process is not disturbed. The helpdesk must have good communicative skills in addition to IT and other skills.

\section{REFERENCES}

Alma, Buchari. 2008. Guru Profesional Menguasai Metode dan Terampil Mengajar. Bandung: Alfabeta.

Arikunto. 2010. Prosedur Penelitian: Suatu Pendekatan Praktik. Jakarta: Rineka Cipta.

DACWP-EV (Development Assistance Committee Working Party on Aid Evaluation). 2002. Glossary of Key Terms in Evaluation and Results Based Management. Paris:OECD. Website: www.oecd.org/dac/ evaluation.

Departemen Pendidikan Nasional. 2003. Undang-undang Republik Indonesia Nomor 20 Tahun 2003 Tentang Sistem Pendidikan Nasional. Jakarta: Departemen Pendidikan Nasional.

Departemen Pendidikan Nasional. 2006. Peraturan Menteri Pendidikan Nasional Nomor 16 Tahun 2006 Tentang Standar Kualifikasi dan Kompetensi Guru, Jakarta: Departemen Pendidikan Nasional.

Directorate General of Higher Education, Ministry of Education. 2003. Higher Education Long Term Strategy 2003-2010. Jakarta: Directorate General of Higher Education, Ministry of Education Republic of Indonesia.

Dirjen GTK Kemendikbud. 2020. Pedoman Program Pendidikan Profesi Guru Dalam Jabatan. Jakarta: Direktorat Pendidikan Profesi dan Pembinaan Guru dan Tenaga Kependidikan.

Hamalik, Oemar. 2002. Psikologi Belajar Mengajar. Bandung: Sinar Baru Algersindo.

Keputusan Presiden Republik Indonesia nomor 11 tahun 2020 tentang Penetapan Kedaruratan Kesehatan Masyarakat Corona Virus Disease 2019 (COVID-19).

Morgan, Clifford T. 2010. Introduction to Psychology. New York: McGraw-Hill Book Company INC.

Pendidikan Tinggi Nomor 44 Tahun 2015 tentang Standar Nasional Pendidikan Tinggi. Permenristekdikti Nomor 55 Tahun 2017 tentang Standar Pendidikan Guru. Jakarta: Kemenristekdikti

Peraturan Menteri Pendidikan dan Kebudayaan Nomor 87 Tahun 2013 tentang Program Pendidikan Profesi Guru Prajabatan.

Peraturan Menteri Pendidikan dan Kebudayaan Nomor 37 Tahun 2017 tentang Sertifikasi Bagi Guru dalam Jabatan yang Diangkat sampai dengan Akhir Tahun 2015. 
Peraturan Menteri Pendidikan Nasional Nomor 16 Tahun 2007 tentang Standar Kualifikasi Akademik dan Kompetensi Guru.

Peraturan Menteri Pendidikan Nasional Nomor 27 Tahun 2008 tentang Standar Kualifikasi Akademik dan Kompetensi Konselor.

Peraturan Pemerintah Nomor 19 Tahun 2017 tentang Perubahan atas Peraturan Pemerintah Nomor 74 Tahun 2008 tentang Guru.

Peraturan Pemerintah Nomor 13 Tahun 2015 tentang Perubahan Kedua atas Peraturan Pemerintah Nomor 19 Tahun 2005 tentang Standar Nasional Pendidikan.

Peraturan Presiden RI Nomor 8 Tahun 2012 tentang Kerangka Kualifikasi Nasional Indonesia $(K K N I)$.

PP 21 tahun 2020 tentang Pembatasan Sosial Berskala Besar dalam rangka Percepatan Penanganan Corona Virus Disease (COVID-19) mengatur tentang Pelaksanaan Pembatasan Sosial Berskala Besar yang ditetapkan oleh Menteri Kesehatan dan dapat dilakukan oleh Pemerintah Daerah berdasarkan persetujuan MenteriKesehatan.

Sugiyono. 2012. Metode Penelitian Kuantitatif Kualitatif dan R\&D. Bandung:Alfabeta

Sukardi. 2009. Metodologi Penelitian Pendidikan: Kompetensi dan Praktiknya, Jakarta: PT Bumi Aksara.

Sukmadinata, Nana Syaodih. 2012. Metode Penelitian Pendidikan, Bandung: PT Remaja Rosdakarya. 